\author{
이탈리안 라이그라스 ‘코윈어리’의 봄철 1회 및 2회 이용에 따른 수확적기 구명 \\ 서 성*·김맹중·김원호·이상학·정민웅·김기용·지희정·박형수·김종근·최기준 \\ 농촌진흥청 국립축산과학원, 천안 331-801
}

\title{
Optimum Harvest Stage of Italian Ryegrass 'Kowinearly' According to One and Two Harvests During Spring Season
}

\author{
Sung Seo*, Won Ho Kim, Meing Jooung Kim, Sang Hak Lee, Min Woong Jung, Ki Yong Kim, Hee Chung Ji, \\ Hyung Soo Park, Jong Geun Kim and Gi Jun Choi
}

National Institute of Animal Science, RDA, Cheonan 331-801, Korea

\begin{abstract}
This study was carried out to determine the optimum harvest stage of Italian ryegrass (Lolium multiflorum Lam., IRG) for maximum forage production during the spring season in Suwon, 2010. The variety of IRG was the early maturity type, 'Kowinearly', and six harvest stages (treatments) were first heading (T1), heading (T2), late heading to early bloom (T3), bloom to late bloom (T4), ripeness (T5), and late ripeness stage (T6). The dates of the first heading and heading of 'Kowinearly' were seen on 4 to 5 May, and 14 May, respectively. Plant length and dry matter(DM) percentage at first harvest were from $69 \mathrm{~cm}$ and $14.8 \%$ at $\mathrm{T} 1$ stage to $103 \mathrm{~cm}$ and $35.0 \%$ at $\mathrm{T} 6$ stage, respectively. The content of crude protein (CP) and in vitro $\mathrm{DM}$ digestibility (IVDMD) of $\mathrm{T} 1, \mathrm{~T} 2, \mathrm{~T} 3, \mathrm{~T} 4, \mathrm{~T} 5$ and $\mathrm{T} 6$ at first harvest were $15.6 \%, 10.6 \%, 10.1 \%, 8.1 \%, 7.3 \%$ and $5.4 \%$, and $81.8 \%, 72.1 \%, 64.8 \%, 63.8 \%, 61.4 \%$ and $59.0 \%$, respectively. The content of neural detergent fiber (NDF) and acid detergent fiber (ADF) were increased continuously with delayed harvest. A significantly higher yield of DM, CP and in vitro digestible DM (IVDDM) were observed for T3, and T4 ( $\mathrm{p}<0.05)$. DM yield of $3,526 \mathrm{~kg}, 6,278 \mathrm{~kg}, 7,842 \mathrm{~kg}, 8,984 \mathrm{~kg}, 8,346 \mathrm{~kg}$ and $8,008 \mathrm{~kg} / \mathrm{ha}$, CP yield of $549 \mathrm{~kg}, 665 \mathrm{~kg}, 795 \mathrm{~kg}, 725 \mathrm{~kg}, 608 \mathrm{~kg}$ and $430 \mathrm{~kg} / \mathrm{ha}$, and IVDDM of 2,883 kg. 4,526 kg, $5,083 \mathrm{~kg}, 5,728 \mathrm{~kg}, 5,124$ $\mathrm{kg}$ and $4,722 \mathrm{~kg} / \mathrm{ha}$ at first harvest were recorded in T1, T2, T3, T4, T5 and T6, respectively. Regrowth yield of DM, CP and IVDDM were shown to be higher at $\mathrm{T} 1$ and $\mathrm{T} 2(\mathrm{p}<0.05)$. However, no significant differences were observed between the two stages. Daily DM and DDM production of regrowth IRG were higher at T2, followed by T1. The total yield (at first and at regrowth) of DM, CP and IVDDM were significant higher for T2, followed by T3, T4 and T1 in order. At T2 stage, the yield was $11,089 \mathrm{~kg}, 1,254 \mathrm{~kg}$, and $7,669 \mathrm{~kg} / \mathrm{ha}$ in DM, CP, and IVDDM. In conclusion, the late heading to bloom stage was determined to be the optimum harvest stage for a single harvest, while the heading stage was a suitable stage of first harvest of 'Kowinearly' where two harvests were sought in a single year.
\end{abstract}

(Key words : Forage productivity, Regrowth, Forage quality, Growth stage, IRG)

\section{I. 서 론}

우리나라의 축우산업은 배합사료와 볏짚 위주로 매년 1,600 만 톤 이상의 배합사료 원료를 수입하고 있으며, 수입 조사료의 물량도 연간 80 90만 톤을 넘고 있어 친환경적 축산의 기본인 자급 조사료 확보에 대한 관심은 그 어느 때보다 높다. 최근 국제 곡물가에 대응하기 위한 정부의 확고한 조사료 정책과 농민들의 의지에 힘입어 사료작물 재배면적은 크게 증가하고 있으며, 특히, 이탈리안 라이그 라스(IRG), 청보리, 호밀 등 월동 사료작물을 중심으로 양질
의 조사료 자급은 점차 정착이 되고 있다(MIFAFF, 2011).

최근 IRG의 재배가 크게 활성화되면서 재배면적은 2009 년도 52.2천 ha, 2011년도에는 60천 ha 이상으로(MIFAFF, 2011) 국내 월동 사료작물 면적과 생산량의 $40 \%$ 이상을 점유하고 있으며, 이는 우리 환경에 맞는 품종개발과 함께 높은 사료가치와 가축 기호성 및 사료화 이용기술의 정착 에 힘입고 있다고 하겠다(Choi et al., 2008; 2011, Seo, 2008; 2009).

$\mathrm{IRG}$ 는 봄철 청예, 건초, 사일리지 등으로 다양하게 이용 할 수 있는데 $(\mathrm{Kim}, 1983)$ 최근에는 원형곤포 사일리지로

* Corresponding author: Sung Seo, National Institute of Animal Science, RDA, Cheonan 331-801, Korea. Tel. +82-41-580-6750, Fax +82-41-580-6779, E-mail: seos9657@korea.kr 
이용이 크게 증가하고 있다(Choi et al., 2008; Seo, 2008). 일반적으로 $\mathrm{IRG}$ 의 수확적기는 출수기에서 개화기로 $(\mathrm{RDA}$, 2011), Choi et al. (2011)은 국내 개발 만생종 '화산 101호' 의 생육단계별 수량과 사료가치를 고려한 수확적기는 출수 $80 \%$ 정도인 수전기에서 개화기로 보고한 바 있다. 그렇지 만 최근 영농현장에서 숙기가 빨라 선호도가 높은 조생종 $\mathrm{IRG}$ 에 대한 생육시기별 사료가치와 수확적기 구명 연구는 거의 없는 편이다(Seo et al., 2011).

본 연구는 국내 개발 품종으로 농가 호응도가 높아 널리 보급되어 있는 조생종 IRG '코윈어리(Kowinearly)'의 수확 시기에 대한 정확한 기술정보를 제공하여 단위면적당 최대 의 생산성을 도모하고자 실시하였으며, 봄철 1 회 이용 시 수확적기와 2 회 이용 시 재생을 고려한 1 차 수확적기를 각 각 구명하였다.

\section{ㅍ. 재료 및 방법}

본 연구는 국내 개발 이탈리안 라이그라스(IRG, Lolium multiflorum Lam.) 중 조생종 '코윈어리 (Kowinearly)'를 공 시하여 2009 2010년 국립축산과학원 사료작물포(수원)에 서 수행되었다. 처리내용(수확기)은 생육시기를 기준하여 출수시 (5월 8일, $\mathrm{T} 1$ ), 출수기 (5월 15일, $\mathrm{T} 2$ ), 출수후기 개 화초기 (5월 22일, T3), 개화기 개화후기 (5월 29일, T4), 등숙기 (6월 5일, T5) 및 등숙후기 (6월 11일, T6) 등 6처 리였다. 봄철 2회 이용구의 1차 수확 후 재생수량은 6 월 11일 전 처리구 동일하게 조사하였다.

시험구는 난괴법 3 반복으로 배치하였으며, 시험구당 면 적은 $6 \mathrm{~m}^{2}(2.0 \times 3.0 \mathrm{~m})$ 였다. 파종은 2009년 9월 30 일 ha당 $40 \mathrm{~kg}$ 의 파종량으로 산파하였으며, 파종 다음 날 트랙터를 이용한 로울러 진압을 해 주었다. 시비량은 질소-인산-칼 리를 $\mathrm{ha}$ 당 각각 140 (1회 수확 시), 200 (2회 수확 시)-120-120 kg을 주었는데, 질소비료는 기비로 $50 \mathrm{~kg}$, 봄철 추비 (2010. 3. 29)로 $90 \mathrm{~kg}$, 그리고 2회 수확구는 1차 수확
후 추비로 $60 \mathrm{~kg}$ 을 시용하였으며, 인산과 칼리비료는 모두 기비로 시용하였다.

처리 간 월동상태, 출수시, 출수기, 개화기, 초장, 도복, 병해발생 등 생육특성과 생초수량, 건물수량 등을 조사하 였으며 (RDA, 2003), 건물수량은 각 처리구별로 $200 ~ 300 \mathrm{~g}$ 의 시료를 취하여 $65 \sim 70^{\circ} \mathrm{C}$ 순환식 송풍건조기에서 $48 \sim 72$ 시 간 건조 후 건물중량을 평량 하여 건물률을 산출한 다음 계산하였다.

조단백질 함량은 Kjeldahl법 (KjeltecTM 2400 Autosampler System)을 이용하여 AOAC (1990)법으로, neutral detergent fiber(NDF)와 acid detergent fiber(ADF)는 Goering and Van Soest (1970)법으로, in vitro 건물 소화율은 Tilley and Terry (1963)법을 Moore (1970)가 수정한 방법으로 분석하였 다. Relative feed value (RFV)는 Holland et al. (1990, DDM $\times \mathrm{DMI} / 1.29)$ 의 계산식에 의해 산출하였으며, 일당 건물생산 량, 일당 가소화 건물생산량 등은 재생기간을 기준하여 계 산하였다.

통계분석은 SAS (2000) 프로그램 (ver. 8.01)을 이용하여 분산분석을 실시하였으며 처리간의 평균비교는 Duncan의 다중검정으로 처리간의 유의성 $(\mathrm{p}<0.05)$ 을 검정하였다. 본 연구에서 $\mathrm{IRG}$ 의 이른 봄 재생 기준일은 3 월 5 일이었으며, 2010년도 봄철 기상은 예년 대비 강우가 잦고 일조시간은 크게 낮아(Table 1) 월동 사료작물의 생육에는 다소 불리 하였을 것으로 추정된다.

\section{III. 결과 및 고찰}

\section{1. 생육시기별 생육특성}

이탈리안 라이그라스(IRG) 'Kowinearly'의 월동 후 생육 상태, 출수시, 출수기, 도복, 병해 등 생육특성은 Table 2에 서 보는바와 같다. 먼저 월동 후 생육상태는 생육시기에 관계없이 양호하였으며, 출수시는 5월 4 5일, 출수기는 5

Table 1. Meteorological data during growing season in Suwon

\begin{tabular}{|c|c|c|c|c|c|c|c|c|}
\hline \multirow{2}{*}{ Item } & \multicolumn{2}{|c|}{ Mean temp. $\left({ }^{\circ} \mathrm{C}\right)$} & \multicolumn{2}{|c|}{ Min. temp. $\left({ }^{\circ} \mathrm{C}\right)$} & \multicolumn{2}{|c|}{ Precipitation(mm) } & \multicolumn{2}{|c|}{ Sunshine(hr) } \\
\hline & 2010 & 30years & 2010 & 30years & 2010 & 30years & 2010 & 30years \\
\hline January & -4.4 & -3.2 & -9.6 & -7.9 & 26.9 & 23.5 & 170.2 & 166.1 \\
\hline February & 1.4 & -1.0 & -2.7 & -5.8 & 56.7 & 24.0 & 151.2 & 170.8 \\
\hline March & 4.6 & 4.5 & 0.5 & -0.7 & 78.7 & 47.0 & 140.7 & 204.5 \\
\hline April & 9.6 & 11.2 & 4.6 & 5.3 & 58.6 & 76.0 & 182.1 & 218.6 \\
\hline May & 17.1 & 16.7 & 11.9 & 11.2 & 100.7 & 94.8 & 197.2 & 233.1 \\
\hline
\end{tabular}

* Suwon Meteorological Station (2010), 30 years $(1971 \sim 2000)$. 
Table 2. Agronomic characteristics of Italian ryegrass 'Kowinearly' at first growth

\begin{tabular}{|c|c|c|c|c|c|c|c|}
\hline Treatment & Growth stage & $\begin{array}{l}\text { Winter-hardiness } \\
\qquad(1 \sim 9)^{*}\end{array}$ & First heading & Heading & $\begin{array}{l}\text { Lodging } \\
(1 \sim 9)^{*}\end{array}$ & $\begin{array}{l}\text { Disease } \\
(1 \sim 9)^{*}\end{array}$ & Remark \\
\hline $\mathrm{T} 1$ & First heading & $1 \sim 2$ & 4 5 May & 14 May & 1 & 1 & - \\
\hline $\mathrm{T} 2$ & Heading & $1 \sim 2$ & " & $"$ & 1 & 1 & - \\
\hline $\mathrm{T} 3$ & Late heading early bloom & $1 \sim 2$ & $"$ & $"$ & 3 & 1 & - \\
\hline $\mathrm{T} 4$ & Bloom late bloom & $1 \sim 2$ & $"$ & $"$ & 5 & $1 \sim 2$ & - \\
\hline $\mathrm{T} 5$ & Ripeness & $1 \sim 2$ & $"$ & $"$ & 7 & 2 & Early shattering \\
\hline T6 & Late ripeness & $1 \sim 2$ & $"$ & $"$ & 9 & 2 & Shattering \\
\hline
\end{tabular}

* 1 (strong) 9 (weak).

월 14 일이었다.

IRG의 숙기와 관련하여 Choi et al. (2008)은 가을에 파 종한 조생종 'Kowinearly'의 출수기는 5월 6일로 본 연구 에 비해 생육이 8일 정도 빠른 것으로 발표하였으며, 또 봄에 파종한 조생종 'Kospeed'의 5월 14일 (Choi et al., 2008), 'Kowinearly'의 5월 16일 (Seo et al., 2011)과 비슷한 것으로 나타났다. 이와 같이 생육이 예년에 비해 늦어진 것은 2010 년도 봄철 기상이 잦은 강우와 일조 부족으로 경 과하였기 때문으로 추정된다 (Table 1).

도복은 출수기까지는 관찰되지 않았지만 출수후기부터 나타났으며, 이 후 생육이 진행될수록 점차 심해져 개화후 기에는 반 이상이 도복되었고 등숙기에는 대부분이 도복되 었다. 전시험구에서 생육 후반부에 잎마름병이 미약한 상 태로 관찰되었으며, 탈립은 등숙기에 약하게 나타났고 등 숙후기에는 상당히 심하였다.

\section{2. 생육시기별 사료가치}

IRG 'Kowinearly'의 조단백질, $\mathrm{NDF}, \mathrm{ADF}, \mathrm{RFV}$, 건물 소화율 등 사료가치는 (Table 3) 수확시기가 늦어질수록 점
차 낮아졌다. 조단백질 함량은 출수시 $15.6 \%$ 에서 등숙후기 에는 $5.4 \%$ 로 감소하였으며, $\mathrm{RFV}$ 는 128 에서 102 로, 건물 소화율은 $81.8 \%$ 에서 $59.0 \%$ 로 낮아졌다. 반면 수확이 늦어 질수록 $\mathrm{NDF}$ 함량은 $49.3 \%$ 에서 $56.4 \%$ 로, $\mathrm{ADF}$ 는 $27.5 \%$ 에 서 $34.6 \%$ 로 높아졌다.

$\mathrm{Seo}(2008)$ 는 일반적인 $\mathrm{IRG}$ 의 조단백질, $\mathrm{NDF}, \mathrm{ADF}$ 함량 은 각각 $10.1 \%, 55.3 \%$ 및 $32.7 \%$ 로 발표하였으며, 가을 파 종 개화기 $\mathrm{IRG}$ 의 조단백질, $\mathrm{NDF}, \mathrm{ADF}$, 건물 소화율은 각 각 $12.4 \%, 54.4 \%, 33.7 \%$ 및 $73.3 \%$ 였고 (Choi et al., 2008), 봄 파종 개화기 IRG는 각각 $11.5 \%, 53.6 \%, 31.9 \%, 73.4 \%$ 였다 (Seo et al., 2011).

한편 만생종 ‘화산 101호'를 공시하여 생육 단계별로 분 석한 건물 소화율은 (Choi et al., 2011) 수잉기 82.8\%, 출수 기 $79.6 \%$, 수전기 $75.3 \%$, 개화기 $73.3 \%$ 라고 하여, 조생종 으로 수행한 본 연구결과에 비해 사료가치는 높은 것으로 나타났다.

\section{3. 생육시기별 사초 수량}

IRG 'Kowinearly'의 초장, 건물률, 건물수량, 조단백질

Table 3. Effect of harvest stage on the forage quality of crude protein (CP), neutral detergent fiber (NDF), acid detergent fiber (ADF), relative feed value (RFV), and in vitro dry matter digestibility (IVDMD) of Italian ryegrass 'Kowinearly' at first growth

\begin{tabular}{lrrrrrr}
\hline \multirow{2}{*}{ Harvest stage at 1st } & \multicolumn{5}{c}{ Forage quality at first growth (\% of DM) } \\
\cline { 2 - 6 } & CP & NDF & ADF & Hemi-cellulose & RFV & IVDMD \\
\hline \hline First heading & 15.6 & 49.3 & 27.5 & 21.8 & 128 & 81.8 \\
Heading & 10.6 & 56.7 & 33.1 & 23.6 & 104 & 72.1 \\
Late heading early bloom & 10.1 & 60.8 & 36.9 & 23.9 & 92 & 64.8 \\
Bloom late bloom & 8.1 & 60.4 & 36.8 & 23.6 & 93 & 63.8 \\
Ripeness & 7.3 & 56.9 & 35.2 & 21.7 & 101 & 61.4 \\
Late ripeness & 5.4 & 56.4 & 34.6 & 21.8 & 102 & 59.0 \\
\hline
\end{tabular}

* The samples within three replications were mixed. 
수량, 가소화 건물수량 및 일당 건물생산량, 일당 가소화 건물생산량은 Table 4에서 보는바와 같다. 수확 시 초장은 출수시 $69 \mathrm{~cm}$ 부터 성숙시 $103 \sim 104 \mathrm{~cm}$ 였으며, 건물률은 출 수시 $14.8 \%$ 에서 생육이 진행될수록 높아져 개화기 개화후 기 $25.5 \%$, 등숙기 $35.0 \%$ 로 개화기 수확까지는 수분함량이 다소 많아 양질의 곤포 사일리지 조제를 위해서는 다소의 예건이 필요하였다 (Seo, 2008).

건물수량과 가소화 건물수량은 개화기 개화후기 수확 시 ha당 각각 $8,984 \mathrm{~kg}, 5,728 \mathrm{~kg}$ 으로 가장 많았으며 $(\mathrm{p}<0.05)$, 다음이 등숙기와 출수후기 개화초기였고, 조단백 질 수량은 출수후기 개화초기에서 $795 \mathrm{~kg}$ 으로 가장 많았 다 $(\mathrm{p}<0.05)$.

한편 일당 건물생산량은 개화기 개화후기 $(105.7 \mathrm{~kg})$ 와 출수후기 개화초기 $(100.5 \mathrm{~kg})$ 에서 유의적으로 높았으며 $(\mathrm{p}<0.05)$, 일당 가소화 건물생산량은 개화기 개화후기 $(67.4$ $\mathrm{kg})$, 출수후기 개화초기 $(65.2 \mathrm{~kg})$, 출수기 $(63.7 \mathrm{~kg})$ 에서 유 의적 차이 없이 높은 경향이었다.

따라서 $\mathrm{IRG}$ 를 봄철에 1 회 수확하여 이용할 경우 수확적 기는 생산량과 사료가치를 고려할 때 출수후기 개화기가 바람직하였다. 이와 관련하여 만생종 ‘화산 101호'로 수행 한 Choi et al. (2011)은 수잉기, 출수시, 수전기, 개화기 수 확 시 건물수량은 각각 ha당 $4,818 \mathrm{~kg}, 7,244 \mathrm{~kg}, 9,147 \mathrm{~kg}$, $9,646 \mathrm{~kg}, \mathrm{TDN}$ 수량은 각각 $3,311 \mathrm{~kg}, 4,806 \mathrm{~kg}, 5,701 \mathrm{~kg}$, $6,009 \mathrm{~kg}$ 으로 수확적기는 수전기에서 개화기였다고 발표한 바 있다.

\section{4. 재생초의 사료가치와 수량}

IRG 'Kowinearly' 1차 수확 후 재생초의 사료가치는 Table 5 에서 보는바와 같다. 1 차 수확시기가 늦어질수록
사료가치는 높아져 1차 생육성적 (Table 3)과는 다른 결과 를 보여주고 있다. 재생초의 사료가치는 출수시에서 개화 기 개화후기로 1 차 수확시기가 늦어질수록 높아져 조단백 질 함량은 $11.0 \%$ 에서 $13.9 \%$ 로, RFV는 87 에서 113 로, 건물 소화율은 $59.1 \%$ 에서 $70.3 \%$ 로 증가하였으며, 반면 $\mathrm{NDF}$ 는 $62.4 \%$ 에서 $53.9 \%$ 로, $\mathrm{ADF}$ 는 $39.3 \%$ 에서 $30.2 \%$ 로 낮아졌다.

Seo et al. (2011)은 출수후기에 수확한 'Kowinearly' 재생 초의 조단백질, $\mathrm{NDF}, \mathrm{ADF}$, 건물 소화율은 각각 $13.2 \%$, $56.4 \%, 35.1 \%$ 및 $70.0 \%$ 라고 발표하여 본 연구결과와 비슷 한 경향이었다.

재생초의 초장, 건물률, 건물수량, 조단백질 수량, 가소화 건물수량, 일당 건물생산량, 일당 가소화 건물생산량은 Table 6에서 보는바와 같다. 초장은 출수시 $91 \mathrm{~cm}$ 부터 개 화기 개화후기 $26 \mathrm{~cm}$, 건물률은 출수시 $25.5 \%$ 부터 개화기 개화후기 $23.8 \%$ 였다.

건물수량, 조단백질 수량, 가소화 건물수량은 1 차 수확기 가 출수시일 때 ha당 각각 $5,425 \mathrm{~kg}, 596 \mathrm{~kg}, 3,204 \mathrm{~kg}$ 으로 많았으나 $(\mathrm{p}<0.05)$, 출수기 수량과는 유의적인 차이는 없었 으며, 출수후기 개화초기와 개화기 개화후기의 생산량은 적었다 $(\mathrm{p}<0.05)$. 한편 1 차 수확이 등숙기로 늦었을 때에는 재생기간이 6 일로 짧고 기온이 높아 재생 수량은 거의 기 대할 수 없었다.

일당 건물생산량은 출수기 $(178.2 \mathrm{~kg})$ 와 출수시 $(159.6 \mathrm{~kg})$ 에서 높았고 $(\mathrm{p}<0.05)$, 일당 가소화건물생산량은 출수기 $(116.4 \mathrm{~kg})$, 출수시 $(94.2 \mathrm{~kg})$, 출수후기 개화초기 $(91.6 \mathrm{~kg})$ 에 서 유의적 차이 없이 높았다 $(\mathrm{p}<0.05)$. 한편 Seo et al. (2011)은 1차 수확을 출수후기에 하였을 때 재생초의 건물

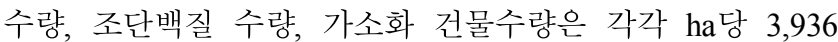
$\mathrm{kg}, 519 \mathrm{~kg}, 2,755 \mathrm{~kg}$ 이라고 하면서 IRG의 재생 우수성을 보고한 바 있다.

Table 4. Effect of harvest stage on the plant length, dry matter (DM) percent, yields of DM, crude protein (CP) and digestible DM (DDM), and daily production of Italian ryegrass 'Kowinearly' at first growth

\begin{tabular}{|c|c|c|c|c|c|c|c|c|}
\hline \multirow{2}{*}{ Harvest stage at $1 \mathrm{st}$} & \multirow{2}{*}{$\begin{array}{c}\text { Plant } \\
\text { length } \\
(\mathrm{cm})\end{array}$} & \multirow{2}{*}{$\begin{array}{l}\mathrm{DM} \\
(\%)\end{array}$} & \multicolumn{3}{|c|}{ Forage yield at first $(\mathrm{kg} / \mathrm{ha})$} & \multirow{2}{*}{$\begin{array}{l}\text { Growth } \\
\text { days }\end{array}$} & \multicolumn{2}{|c|}{$\begin{array}{c}\text { Daily production } \\
(\mathrm{kg} / \mathrm{ha})\end{array}$} \\
\hline & & & $\mathrm{DM}$ & $\mathrm{CP}$ & DDM & & DM & DDM \\
\hline First heading & 69 & 14.8 & $3,526^{\mathrm{c}}$ & $549^{\mathrm{cd}}$ & $2,883^{\mathrm{b}}$ & 64 & $55.1^{\mathrm{c}}$ & $45.0^{\mathrm{b}}$ \\
\hline Heading & 86 & 19.5 & $6,278^{b}$ & $665^{\mathrm{abc}}$ & $4,526^{\mathrm{a}}$ & 71 & $88.4^{\mathrm{ab}}$ & $63.7^{\mathrm{a}}$ \\
\hline Late heading early bloom & 99 & 19.5 & $7,842^{\mathrm{ab}}$ & $795^{\mathrm{a}}$ & $5,083^{\mathrm{a}}$ & 78 & $100.5^{\mathrm{ab}}$ & $65.2^{\mathrm{a}}$ \\
\hline Bloom late bloom & 104 & 25.5 & $8,984^{\mathrm{a}}$ & $725^{\mathrm{ab}}$ & $5,728^{\mathrm{a}}$ & 85 & $105.7^{\mathrm{a}}$ & $67.4^{\mathrm{a}}$ \\
\hline Ripeness & 103 & 29.2 & $8,346^{\mathrm{a}}$ & $608^{\mathrm{bc}}$ & $5,124^{\mathrm{a}}$ & 92 & $90.7^{\mathrm{ab}}$ & $55.7^{\mathrm{ab}}$ \\
\hline Late ripeness & - & 35.0 & $8,008^{\mathrm{ab}}$ & $430^{\mathrm{d}}$ & $4,722^{\mathrm{a}}$ & 98 & $81.7^{\mathrm{b}}$ & $48.2^{\mathrm{b}}$ \\
\hline
\end{tabular}

a,b,c,d Means in the same column with different letter were significantly different $(\mathrm{p}<0.05)$. 
Table 5. Effect of harvest stage on the forage quality of crude protein (CP), neutral detergent fiber (NDF), acid detergent fiber (ADF), relative feed value (RFV), and in vitro dry matter digestibility (IVDMD) of Italian ryegrass 'Kowinearly' at regrowth

\begin{tabular}{lccccrr}
\hline \multirow{2}{*}{ Harvest stage at 1st } & \multicolumn{5}{c}{ Forage quality at regrowth (\% of DM) } \\
\cline { 2 - 7 } & CP & NDF & ADF & Hemi-cellulose & RFV & IVDMD \\
\hline \hline First heading & 11.0 & 62.4 & 39.3 & 23.1 & 87 & 59.1 \\
Heading & 12.2 & 59.9 & 36.5 & 23.4 & 94 & 65.3 \\
Late heading early bloom & 17.1 & 54.5 & 30.9 & 23.6 & 111 & 72.9 \\
Bloom late bloom & 13.9 & 53.9 & 30.2 & 23.7 & 113 & 70.3 \\
Ripeness & + & + & + & + & + & + \\
\hline
\end{tabular}

* Harvested at 11 June, The samples within three replications were mixed.

Table 6. Effect of harvest stage on the plant length, dry matter (DM) percent, yields of DM, crude protein (CP) and digestible DM (DDM), and daily production of Italian ryegrass 'Kowinearly' at regrowth

\begin{tabular}{|c|c|c|c|c|c|c|c|c|c|}
\hline \multirow{2}{*}{ Harvest stage at $1 \mathrm{st}$} & \multirow{2}{*}{$\begin{array}{l}\text { Growth stage } \\
\text { at } 2 \text { nd }\end{array}$} & \multirow{2}{*}{$\begin{array}{c}\text { Plant } \\
\text { length } \\
(\mathrm{cm})\end{array}$} & \multirow{2}{*}{$\begin{array}{l}\mathrm{DM} \\
(\%)\end{array}$} & \multicolumn{3}{|c|}{$\begin{array}{c}\text { Forage yield at regrowth } \\
(\mathrm{kg} / \mathrm{ha})\end{array}$} & \multirow{2}{*}{$\begin{array}{l}\text { Growth } \\
\text { days }\end{array}$} & \multicolumn{2}{|c|}{$\begin{array}{c}\text { Daily production } \\
(\mathrm{kg} / \mathrm{ha})\end{array}$} \\
\hline & & & & DM & $\mathrm{CP}$ & $\mathrm{DDM}$ & & $\mathrm{DM}$ & $\mathrm{DDM}$ \\
\hline First heading & Late flowering & 91 & 25.5 & $5,425^{\mathrm{a}}$ & $596^{\mathrm{a}}$ & $3,204^{\mathrm{a}}$ & 34 & $159.6^{\mathrm{ab}}$ & $94.2^{\mathrm{a}}$ \\
\hline Heading & Flowering & 71 & 26.5 & $4,811^{\mathrm{a}}$ & $589^{\mathrm{a}}$ & $3,143^{\mathrm{a}}$ & 27 & $178.2^{\mathrm{a}}$ & $116.4^{\mathrm{a}}$ \\
\hline Late heading early bloom & Heading & 42 & 20.2 & $2,512^{\mathrm{b}}$ & $430^{\mathrm{b}}$ & $1,832^{\mathrm{b}}$ & 20 & $125.6^{\mathrm{b}}$ & $91.6^{\mathrm{a}}$ \\
\hline Bloom late bloom & Vegetative heading & 26 & 23.8 & $949^{\mathrm{c}}$ & $131^{\mathrm{c}}$ & $667^{\mathrm{c}}$ & 13 & $73.0^{\mathrm{c}}$ & $51.3^{\mathrm{b}}$ \\
\hline Ripeness & Vegetative & + & + & + & + & + & 6 & + & + \\
\hline
\end{tabular}

${ }^{\mathrm{a}, \mathrm{b}, \mathrm{c}}$ Means in the same column with different letter were significantly different $(\mathrm{p}<0.05)$.

\section{2회 수확 시 총 사초수량과 1차 수확적기}

IRG 'Kowinearly'의 재생을 고려한 총 수량 및 전 기간 일당생산량 등은 Table 7에서 보는바와 같다. 총 건물수량, 총 조단백질 수량, 총 가소화 건물수량은 1 차 수확을 출수 기에 했을 때 ha당 각각 $11,089 \mathrm{~kg}, 1,254 \mathrm{~kg}, 7,669 \mathrm{~kg}$ 으 로 가장 많은 경향이었으나, 출수후기 개화초기, 개화기 개화후기, 출수시 수량과 유의적인 차이는 인정되지 않았
다 $(\mathrm{p}<0.05)$.

전 기간 일당 건물생산량, 조단백질 생산량 및 가소화 건물생산량은 출수기에서 각각 $113.2 \mathrm{~kg}, 12.8 \mathrm{~kg}, 78.3 \mathrm{~kg}$ 으로 유의적으로 높았으며, 다음이 출수후기 개화초기로 각각 $105.7 \mathrm{~kg}, 12.5 \mathrm{~kg}, 70.6 \mathrm{~kg}$ 이었다 $(\mathrm{p}<0.05)$. 따라서 봄 철에 2 회 수확하여 이용할 경우 1 차 수확은 출수기에 하는 것이 재생을 포함한 총 생산량과 일당 생산량 및 사료가치 측면에서 유리하다고 보여진다.

Table 7. Effect of harvest stage on the total forage yields of dry matter (DM), crude protein (CP) and digestible DM (DDM), and daily production of Italian ryegrass 'Kowinearly'

\begin{tabular}{|c|c|c|c|c|c|c|c|}
\hline \multirow{3}{*}{ Harvest stage at 1 st } & \multirow{3}{*}{$\begin{array}{c}\text { Growth } \\
\text { days }\end{array}$} & \multicolumn{6}{|c|}{ Total forage yield $(\mathrm{kg} / \mathrm{ha})$} \\
\hline & & \multicolumn{2}{|c|}{$\mathrm{DM}$} & \multicolumn{2}{|c|}{$\mathrm{CP}$} & \multicolumn{2}{|c|}{ DDM } \\
\hline & & Total & Daily & Total & Daily & Total & Daily \\
\hline First heading & 98 & $8,951^{\mathrm{abc}}$ & $91.3^{\mathrm{abc}}$ & $1,145^{\mathrm{a}}$ & $11.7^{\mathrm{a}}$ & $6,087^{\mathrm{bc}}$ & $62.1^{\mathrm{bc}}$ \\
\hline Heading & 98 & $11,089^{\mathrm{a}}$ & $113.2^{\mathrm{a}}$ & $1,254^{\mathrm{a}}$ & $12.8^{\mathrm{a}}$ & $7,669^{\mathrm{a}}$ & $78.3^{\mathrm{a}}$ \\
\hline Late heading early bloom & 98 & $10,354^{\mathrm{ab}}$ & $105.7^{\mathrm{ab}}$ & $1,225^{\mathrm{a}}$ & $12.5^{\mathrm{a}}$ & $6,915^{\mathrm{ab}}$ & $70.6^{\mathrm{ab}}$ \\
\hline Bloom late bloom & 98 & $9,933^{\mathrm{abc}}$ & $101.4^{\mathrm{abc}}$ & $856^{\mathrm{b}}$ & $8.7^{\mathrm{b}}$ & $6,395^{\mathrm{abc}}$ & $65.3^{a b c}$ \\
\hline Ripeness & 98 & $8,346^{\mathrm{bc}}$ & $85.2^{\mathrm{bc}}$ & $608^{\mathrm{c}}$ & $6.2^{\mathrm{c}}$ & $5,124^{\mathrm{cd}}$ & $52.3^{\mathrm{cd}}$ \\
\hline Late ripeness & 98 & $8,008^{\mathrm{c}}$ & $81.7^{\mathrm{c}}$ & $430^{\mathrm{c}}$ & $4.4^{\mathrm{c}}$ & $4,722^{\mathrm{d}}$ & $48.2^{\mathrm{d}}$ \\
\hline
\end{tabular}

a,b,c,d Means in the same column with different letter were significantly different $(\mathrm{p}<0.05)$. 
이상의 결과를 종합하여 볼 때, 양질의 월동 사료작물인 IRG 조생종 'Kowinearly'를 봄철에 1회 수확하여 이용할 경우 단위면적당 생산량과 사료가치를 고려한 수확적기는 출수후기 개화기이며, 봄철 2회 수확하여 이용할 경우 재 생과 단위면적당 총 생산량을 고려한 1 차 수확적기는 출수 기가 유리하다고 판단된다.

\section{IV. 요 약}

본 연구는 국내 개발 이탈리안 라이그라스(IRG)의 봄철 1 회 및 2회 이용 시 수확적기를 구명하고자 국립축산과학 원 (수원)에서 조생종 'Kowinearly' 품종을 공시, 2009년 9 월 30일에 파종하여 2010년 6월까지 수행하였다. 처리내용 은 1차 수확시기로 출수시 (T1), 출수기 (T2), 출수후기 개 화초기 (T3), 개화기 개화후기 (T4), 등숙기 (T5) 및 등숙후 기 (T6) 등 6처리였으며, 2차 수량조사는 6월 11일 동일하 게 실시하였다. 'Kowinearly'의 출수시는 5월 4 5일, 출수 기는 5 월 14 일, 도복은 개화 이후 많이 관찰되었다. 건물률 은 T1 $14.8 \%$ 에서 T6 $35.0 \%$ 로 생육진행에 따라 높아졌으 며, 조단백질, $\mathrm{RFV}$, 건물 소화율 등 사료가치는 생육 지연 에 따라 낮아졌다. 건물수량과 가소화 건물수량은 $\mathrm{T} 4$ 에서 $\mathrm{ha}$ 당 각각 $8,984 \mathrm{~kg}$ 과 $5,728 \mathrm{~kg}$ 으로, 조단백질 수량은 $\mathrm{T} 3$ 에 서 $795 \mathrm{~kg}$ 으로 유의적으로 높았으며 $(\mathrm{p}<0.05)$, 재생초의 건 물수량, 조단백질 수량, 가소화 건물수량은 $\mathrm{T} 1$ 과 $\mathrm{T} 2$ 에서 차이 없이 각각 $5,425 \mathrm{~kg}, 596 \mathrm{~kg}, 3,204 \mathrm{~kg}$ (T1)과 $4,811 \mathrm{~kg}$, $589 \mathrm{~kg}, 3,143 \mathrm{~kg}$ (T2)으로 유의적으로 높았다 $(\mathrm{p}<0.05)$. 총 건물수량, 조단백질 수량, 가소화 건물수량은 $\mathrm{T} 2$ 와 $\mathrm{T} 3$ 에서 차이 없이 각각 $11,089 \mathrm{~kg}, 1,254 \mathrm{~kg}, 7,669 \mathrm{~kg}$ (T2)과 10,354 $\mathrm{kg}, 1,225 \mathrm{~kg}, 6,915 \mathrm{~kg}$ (T3)으로 유의적으로 높았다 $(\mathrm{p}<0.05)$. 일당 건물생산량과 일당 가소화건물생산량은 1 차 생육은 $\mathrm{T} 2, \mathrm{~T} 3, \mathrm{~T} 4$ 에서, 재생초는 $\mathrm{T} 2, \mathrm{~T} 1$ 에서 높았으며, 전 기간 일당생산량에서는 출수기인 $\mathrm{T} 2$ 에서 가장 높았고 다음이 $\mathrm{T} 3, \mathrm{~T} 4, \mathrm{~T} 1$ 순이었다. 이상의 결과를 종합하여 볼 때, IRG 'Kowinearly'를 봄철에 1회 수확하여 이용할 경우 단위면적 당 생산량과 사료가치를 고려한 수확적기는 출수후기 개 화기이며, 봄철 2회 수확하여 이용할 경우 재생과 단위면 적당 총 생산량을 고려한 1 차 수확적기는 출수기가 유리하 다고 판단된다.

\section{$\mathrm{V}$. 인 용 문 헌}

AOAC. 1990. Official methods of analysis (15th ed.). Association of
Official Analytical Chemists, Washington DC.

Choi, G.J., Kim, W.H. and Seo, S. 2008. Production and utilization of Italian ryegrass and barley as winter annual forages in Korea. Proceedings of 2008 Annual Congress of Korean Society of Grassland and Forage Science. pp. 17-48.

Choi, G.J., Lim, Y.C., Ji, H.J., Lee, S.H., Lee, K.W., Kim, D.K., Seo, S. and Kim, K.Y. 2011. Change in dry matter yields and feed values of Italian ryegrass, Hwasan 101, at different growth stages. Journal of the Korean Grassland and Forage Science. $31: 107-112$.

Goering, H.K. and Van Soest, P.J. 1970. Forage fiber analysis. USDA Agricultural Handbook No. 379, USDA. Washington, DC.

Holland, C., Kezar, W., Kautz, W.P., Lazowski, E.J., Mahanna, W.C. and Reinhart, R. 1990. The Pioneer Forage Manual-A Nutritional Guide. Pioneer Hi-Bred International, Inc., Des Moines, Iowa, USA.

Kim, D.A. 1983. Forage crops. Seonjin Publish Company. Seoul. pp. 309-320.

MIFAFF. 2011. Forage production and utilization for animal production. Ministry for Food, Agriculture, Forest and Fisheries.

Moore, R.E. 1970. Procedure for the two-stage in vitro digestion of forage. University of Florida, Department of Animal Science.

RDA. 2003. Investigation and Analysis of Research and Technology in Agriculture (Forages). Rural Development Administration.

RDA. 2011. Forages. Standard Agriculture Farming Text-91. Rural Development Administration. pp. 69-78.

SAS. 2000. SAS User's Guide. Version 8.01. SAS Institute Inc., Cary North Caroline, USA.

Seo, S. 2008. Development and utilization of domestic forage resources. Proceedings of 2008 Annual Congress of Korean Society of the Animal Science and Technology (Vol. 1) pp. 99-114.

Seo, S. 2009. Development of new varieties and production of forages in Korea. Journal of the Korean Grassland and Forage Science. 29:1-10.

Seo, S., Kim, W.H., Kim, K.Y., Jung, M.W., Choi, G.J., Park, H.S. and Lee, J.K. 2011. Effect of early harvest on the forage yield, quality and regrowth of Italian ryegrass and barley sown in early spring. Journal of the Korean Grassland and Forage Science. 31:39-46

Tilley, J.M.A. and Terry, R.A. 1963. A two-stage technique for the in vitro digestion of forage crops. Journal of the British Grassland Society 18:104-111.

(Received January 5, 2013/Accepted January 29, 2013) 